\title{
An Investigation of Prospective Science Teachers' Conceptions towards the Nature of Scientific Knowledge"
}

\author{
Şeyda GÜL ${ }^{* *}$
}

\author{
Mehmet ERKOL ${ }^{* * *}$
}

\begin{abstract}
The aim of this study is to determine prospective science teachers' conceptions about the nature of scientific knowledge and to investigate their conceptions in terms of different variables. The sample comprised of 196 prospective science teachers from Ataturk University during the 2013-2014 spring semester. The Nature of Scientific Knowledge Scale, which was developed by Rubba \& Andersen (1978) and adopted by Kılıç, Sungur, Çakıroğlu, \& Tekkaya (2005), was used. The data were analyzed using descriptive statistics and multivariate analysis of variance (MANOVA). The findings indicated that prospective teachers generally had moderate-level conceptions about the nature of scientific knowledge. The findings also indicated that there was a statistically significant difference in terms of grade level, but not gender.
\end{abstract}

Keywords: The nature of scientific knowledge, science prospective teacher, conception.

\section{Extended Abstract}

Purpose and Significance: A perennial goal of science education is to help the students' developing the informed conceptions of nature of science (NOS). This goal has gained renewed emphasis in current national science education reform documents such as American Association for the Advancement of Science [AAAS] and National Research Council [NRC] (Abd-El-Khalick, 2001). An adequate understanding of the nature of science is a central component of scientific literacy (Bell \& Ledermann, 2003). Scientific literacy is defined as knowing science of nature, understanding how the information is obtained, perceiving that knowledge in science is due to known facts and this may change as the new evidences are collected, knowing main concepts, theories and hypotheses in sciences and perceiving difference between scientific evidence and personal opinion (Tan \& Temiz, 2003).

\footnotetext{
${ }^{*}$ This article was presented at ICSSER - 1st International Conference on Social Sciences and Education Research which was held between October 29-31, 2015 in Antalya-TURKEY.

${ }^{* *}$ Corresponding Author: Assist. Prof. Dr., Atatürk University, Erzurum, Turkey, seydagul@atauni.edu.tr

*** Assist. Prof. Dr., Afyon Kocatepe University, Afyonkarahisar, Turkey, merkol@aku.edu.tr
}

\section{Citation Information}

Gül, Ş., \& Erkol, M. (2016). Fen bilgisi öğretmeni adaylarının bilimsel bilginin doğası anlayışlarının incelenmesi. Kuramsal Eğitimbilim Dergisi [Journal of Theoretical Educational Science], 9(4), 642-661. 
According to Akerson \& Abd-El-Khalick (2005):

- scientific knowledge is both reliable (one can have confidence in scientific knowledge) and tentative (subject to change considering new evidence or reconceptualization of prior evidence)

- no single scientific method exists, but there are shared characteristics of scientific approaches to science such as scientific explanations being supported by empirical evidence and that they are testable against the natural world

- creativity plays a role in the development of scientific knowledge

- there is a relationship between theories and laws

- there is a relationship between observations and inferences

- Though science strives for objectivity, there is always an element of subjectivity in the development of scientific knowledge

- Social and cultural context also play a role in the development of scientific knowledge.

To understand the nature of science to students has been one of the major goals of science education for many years (AAAS, 1993; Çil \& Çepni, 2012; NRC, 1996). As known, NOS is a vital element for educating scientifically literate generations. Hence, NOS in our country as many countries all around the world (e.g., US, The Netherlands, South Africa, Great Britain), is a part of science curricula (Şardağ et al., 2014). But, it is reported that Turkish students, prospective teachers and teachers' conceptions and knowledge towards NOS are inadequate and has misconceptions in addition to failure of the science program in developing the students'conceptions to NOS (Altun-Yalçın et al., 2010; Çil \& Çepni, 2012; Gürses, Doğar, \& Yalçın, 2005; Köseoğlu, Tümay, \& Budak, 2008; Taşar, 2003). One of the most important causes of these deficiencies is probably teachers. Therefore, it is important to determine to conceptions of prospective teachers who are also future teachers. Thus, the aim of this study is to determine prospective science teachers' conceptions towards the nature of scientific knowledge and to investigate in terms of different variables.

Methods: Survey method, which is among non-experimental designs of quantitative approach, was used to guide the process. In this study, a Likert type "Nature of Scientific Science Scale", which was developed by Rubba and Andersen (1978) and adapted to Turkish by Kılıç, Sungur, Çakıroğlu and Tekkaya (2005), was used. The scale was applied to totally 196 prospective science teachers who attend to Kazim Karabekir Education Faculty at Ataturk University. The scale included in 48 items, totally 6 subscales named "amoral", "creative", "developmental", "parsimonious", "testable" and "unified". SPSS (Statistical Package for the Social Sciences) package program was used in analyzing the data. Mean values, standard deviations and MANOVA tests were conducted. 
Results: This study searched the answers for three questions. Concerning with the answers to these questions, firstly, descriptive statistics were calculated in order to determine the general levels of prospective teachers 'conceptions. The findings indicated that they had average levels for all sub-dimensions in the scale. Secondly, MANOVA was done if there was a difference between genders in terms of scores in scale. MANOVA test revealed that there was no statistically significant difference between genders ( $p>0.05)$ and also females' mean scores were higher than males in majority of sub-dimensions in the scale. Third, MANOVA was done in order to determine if there was a difference between grades in terms of scores in scale. MANOVA test revealed that there was a statistically significant difference between grades $(\mathrm{p}<0.05)$ and also all graders had the mid-level scores for statements in the scale. The findings also indicated that $4^{\text {th }}$ graders had less score than the others.

Discussion and Conclusions: The findings indicated that prospective teachers have generally moderate conceptions towards the nature of scientific knowledge. The findings also indicated that there was a statistically significant difference in terms of grade but no gender. According to the findings of this study, it can be said that more studies should be done to examine thoroughly and to find reasons the factors which lead to prospective teachers' conceptions in this subject. Moreover, students and teachers must be informed about the nature of science. In addition, although the generalizability of this study might be limited by the sample size and prospective science teachers' background, we believe that findings of this study may help science educators in their future studies on development of understanding towards nature of science. 


\title{
Fen Bilgisi Öğretmeni Adaylarının Bilimsel Bilginin Doğası Anlayışlarının İncelenmesi*
}

\author{
Şeyda GÜL ${ }^{* *} \quad$ Mehmet ERKOL ${ }^{* * *}$
}

Makale Gönderme Tarihi: 29 Ağustos 2014

Makale Kabul Tarihi: 04 Ocak 2016

ÖZ: Bu çalışmada fen bilgisi öğretmeni adaylarının bilimsel bilginin doğasına yönelik anlayışlarının belirlenmesi ve farklı değişkenler (cinsiyet ve sınıf düzeyi) açısından incelenmesi amaçlanmıştır. Çalışmanın örneklemini 2013-2014 eğitim-öğretim yılı bahar döneminde Atatürk Üniversitesi fen bilgisi eğitimi anabilim dalında öğrenim gören 196 öğretmen adayı oluşturmaktadır. Çalışmada veri toplama aracı olarak Rubba \& Andersen (1978) tarafindan geliştirilen ve Kılıç, Sungur, Çakıroğlu \& Tekkaya (2005) tarafindan Türkçeye uyarlanan Bilimin Doğası Ölçeği kullanılmıştır. Verilerin analizinde ise betimsel istatistikler ve çok değişkenli varyans analizi (MANOVA) kullanılmıştır. Elde edilen bulgular, öğretmen adaylarının bilimsel bilginin doğasına yönelik anlayışlarının genel anlamda orta düzey düzeyde olduğu göstermiştir. Ayrıca, cinsiyet açısından öğretmen adaylarının puanları arasında anlamlı bir farklılık olmamasına rağmen sınıf düzeyleri açısından ahlâki, test edilebilirlik ve bütünlük boyutlarında anlamlı farklılıkların ortaya çıktı̆g 1 belirlenmiştir.

Anahtar kelimeler: Bilimsel bilginin doğası, fen bilgisi öğretmen adayı, anlayış.

\section{Giriş}

Çağımızda bilim; sosyal, kültürel ve ekonomik hayatımızın önemli bir parçası olmuştur. $\mathrm{Bu}$ yüzden günümüzün demokratik toplumları bilimi ve bilimin topluma katkısını takdir eden, bilimin işleyişi ve bilimin ortaya koyduğu temel fikirler hakkında yeterli bilgiye sahip ve en önemlisi, bilimin ortaya koyduğu bilgi ve tartışmalara eleştirel yaklaşabilen bireylere, yani bilimsel okur-yazar bireylere ihtiyaç duymaktadır (Milli Eğitim Bakanlığ1 [MEB], 2013). Bu bağlamda fen eğitimin ve eğitimcilerinin en önemli amaçları arasında bireylerin bilimsel okuryazar olarak yetiştirilmesinin yer aldığ görülmektedir (Abd-El-Khalick, Bell, \& Lederman, 1998; Abd-El-Khalick, 2001; American Association for the Advancement of Science [AAAS], 1990; National Research Council [NRC], 1996).

Alan yazında bilimsel okuryazarlık, dünyanın nasıl çalıştığını anlama, olaylar karşısında mantıklı çözümler üretme olarak tanımlanmaktadır (AAAS, 1993). Bilimin doğasının anlaşılması ise bilim okuryazarı olan bireyleri yetiştirmenin bir gerekliliği olarak görülmektedir (Kaya \& Çakmaçı, 2012).

Bilimin doğasına yönelik alan yazında birçok tanım yapılmakla birlikte, bilimin doğası konusu araştırmacılar tarafından net bir şekilde tanımlanamamıştır. Bununla beraber Lederman (1992) bilimin doğasının; bilimin epistemolojisini ve sosyal yapısını yansıtan, bilgiyi oluşturma yolunu ve bilimsel bilginin oluşturulmasındaki değer ve inanışları temsil ettiğini ifade etmektedir.

*Bu makale 29-31 Ekim tarihleri arasında Antalya-Türkiye'de düzenlenen ICSSER - Sosyal Bilimler ve Eğitim Araştırmaları Birinci Uluslararası Konferansı'nda sunulmuştur.

${ }^{* *}$ Sorumlu Yazar: Yrd. Doç. Dr., Atatürk Üniversitesi, Erzurum, Turkey, seydagul@ atauni.edu.tr

**** Yrd. Doç. Dr., Afyon Kocatepe Üniversitesi, Afyonkarahisar, Turkey, merkol @aku.edu.tr 
Akerson \& Abd-El-Khalick (2005) göre bilimin doğasına ait temel özellikler şu şekilde sıralanmaktadır:

- Bilimsel bilgi hem güvenilir hem de geçicidir, yani yeni delillerle değişebilir.

- Tek bir bilimsel metot yoktur. Bilim üretmenin deneysel kanitlarla desteklenebilen birden çok yolu vardır.

- Bilimsel bilginin üretilmesinde yaratıcılığın önemli bir rolü vardır.

- Teori ve kanunlar arasında bir ilişki vardır.

- Gözlem ve çıkarımlar arasında bir ilişki vardır.

- Bilim her ne kadar objektif olmaya çalışsa da, bilimsel bilginin üretilmesinde daima sübjektiflik etkisi vardır.

- Bilimsel bilginin üretilmesinde sosyal ve kültürel ortam önemli bir rol oynar.

Bilimin doğasını öğrencilere kavratmak, uzun yıllardan beri fen eğitiminin önemli amaçlarından biri olmuştur (AAAS, 1993; Çil \& Çepni, 2012; NRC, 1996). Bunun için Driver, Leach, Millar, \& Scott (1996), beş neden ileri sürmüştür. Bu nedenler:

(a) Bilimin doğası bireylerin bilimi, bilimin ürünlerini ve günlük yaşamda karşılaşılan yöntemlerini anlamasını sağlayabildiği,

(b) bireylerin bilimle ilgili sorunlar hakkındaki tartışmalara katılmasına yardımcı olabildiği,

(c) bilimin doğasının anlaşılmasının bireylerin bilimsel kültüre değer vermelerini sağlayabildiği,

(d) bireylerin bilimsel toplumun normlarını anlamalarını sağlayabildiği ve fen konu alanının daha etkin bir şekilde öğrenilmesine yardımcı olabildiğidir (Akt: Bilen, 2012).

Yukarıda sıralanan nedenler doğrultusunda günümüzde birçok eğitimci de bilimin doğasının fen öğretim programları kapsamına alınması ve öğretilmesi gerektiğini savunmaktadır (Altun-Yalçın, Kahraman, Açışlı \& Yılmaz, 2010; Hogan, 2000). Bu doğrultuda son yıllarda eğitim alanındaki reformlar öğrencilerin yanında öğretmenlerin de bilimin doğası hakkında geçerli kavram ve anlayışa sahip olmasını amaçlamaktadır. Bu reform çalışmaları iki varsayıma dayanmaktadır:

1. Öğretmenlerin sahip oldukları bilimin doğası ile ilgili kavramlar direkt olarak onların sınıf içi performanslarına ve aktivitelerine etki eder.

2. Öğretmenlerin bilimin doğası hakkındaki bilgi ve anlayışlarının, öğrencilerinin bu konudaki kavramları ve anlayışları üzerine direkt bir etkisi vardır (Akçay, 2006).

Bilindiği üzere, dünyada birçok ülkede olduğu gibi (örneğin Amerika Birleşik Devletleri, Hollanda, Güney Afrika, Büyük Britanya), ülkemizde de bilimin doğası fen öğretim programlarında yer almaktadır (Şardağ ve diğerleri, 2014). Ayrıca üniversitelerde de bilim tarihi ve bilim felsefesi dersleri kapsamında bilimin doğası eğitimi verilmektedir. Ancak, özellikle Türkiye'de öğrencilerin, öğretmen adaylarının ve öğretmenlerin bilimin doğası ile ilgili anlayışlarını inceleyen çalışmalarda bu konuda önemli öğretim eksiklikleri olduğu, okullarda uygulanmakta olan fen eğitiminin öğrencilerin bilimin doğası hakkında çağdaş görüşler kazanmasında yetersiz kaldığı ve hatta bu konuda kavram yanılgılarının 
oluşmasına yol açtı̆̆ı rapor edilmektedir (Altun-Yalçın ve diğerleri, 2010; Çil \& Çepni, 2012; Gürses, Doğar \& Yalçın, 2005; Köseoğlu, Tümay \& Budak, 2008; Taşar, 2003). Ayrıca, 1999 TIMSS-R raporu ve 2006 PISA gibi uluslararası karşılaştırma ve değerlendirme raporları da, bilimin doğası ile ilgili çeşitli alt-ölçekler yönünden Türkiye'nin konumunun sürekli olarak en alt seviyelerde olduğunu göstermektedir (Köseoğlu ve diğerleri, 2008).

Elbette bu konuda yukarıda ifade edilen yetersizliklerin en önemli nedenlerinden birinin, eğitim-öğretimden sorumlu olan öğretmenler olabileceği düşünülmektedir (Seçkin, 2013). Zira öğretmenlerin sınıf içi öğrenme ve öğretim faaliyetleri ve öğrenciler için belirleyeceği amaçtan tutun da dersi işleyiş tarzı ve değerlendirme yöntemine kadar hemen her faaliyet, öğretmenlerin bilim felsefesi ve bilimin doğası hakkındaki görüşünün etkisi altında bulunmaktadır. Dolayısıyla öğretmen adaylarının da öğrenmeleri, kendilerinin bilim anlayışlarıyla yakından ilgilidir (Bilen, 2012). Nitekim Türkmen \& Yalçın (2001) da bu konuya dikkati çekerek, özellikle fen bilgisi veya fen grubu öğretmenleri eğer öğrencilere tamamen fen bilimlerinin içeriğini ve bilim felsefesini kavratmak istiyorlarsa onların bilimsel çalışmaların ve bilimin doğasının fen bilgisi eğitimiyle nasıl ilişkili olduğunun farkında olmaya ihtiyaçları olduğunu ifade etmişleridir. Bu durum dikkate alındığında, son yıllarda birçok çalışmada da dikkatlerin öğretmenler ve öğretmen adayları üzerine yoğunlaştığ 1 ve onların bilimin doğası ile ilgili görüşlerinin belirlenmeye çalışıldığı görülmektedir (Aslan, Yalçın \& Taşar, 2009). Bu konu ile ilgili olarak örneğin Aslan ve diğerleri (2009) tarafından fen ve teknoloji öğretmenlerinin bilimin doğasına yönelik görüşlerinin saptanması amacıyla yapılan bir çalışmada, bilimin tanımı, gözlemlerin doğası, bilimsel bilginin değişkenliği, önerme, kuram ve yasaların yapısı ve bilimsel yöntemle ilgili olarak fen ve teknoloji öğretmelerinin yetersiz ve yanlış birtakım görüşlere sahip oldukları tespit edilmiştir. Yine Akçay (2011) tarafından yapılan çalışmanın sonuçları, fen ve teknoloji öğretmenlerinin bilimin doğasına yönelik inanışları incelenmiş, elde edilen verilerin değerlendirilmesi sonucunda öğretmenlerin bilimin doğası ile ilgili konularda kavram yanılgılarına ve yetersiz bilgiye sahip olduklarını göstermiştir.

Altın-Yalçın ve diğerleri (2010), fen bilgisi öğretmeni adaylarının bilimin doğası konusundaki görüşlerinin tespit edilmesi amacıyla bir çalışma yapmışlardır. Çalışmanın sonuçları, öğretmen adaylarının büyük bir bölümünün bilimin doğası konusunda çağdaş bakış açısına sahip olduklarını ve teori ve kanun konusunda yaygın kavram yanılgılarına sahip olduklarını göstermiştir.

Yalçın \& Yalçın (2011) tarafından ilkokul öğretmenlerinin akademik düzeylerine göre bilimin doğası ile ilgili görüşlerini ortaya koymak amacı ile yapılan çalışmada, öğretmen adaylarının bilimin doğası ile ilgili kabul edilebilir görüşlere sahip oldukları ortaya çıkmıştır. Ayrıca, öğretmen adaylarının cinsiyete ve akademik düzeye göre bilimin doğası ile ilgili görüşleri arasında anlamlı bir farklılık olmadığı görülmüştür.

Aslan \& Taşar (2013) ise fen öğretmenlerinin bilimin doğası hakkındaki görüşlerini incelemek ve bu görüşlerin onların sınıf içi uygulamalarını nasıl etkilediğini belirlemek maçıyla 74 fen öğretmeni ile bir çalışma yürütmüştür. Çalışmadan elde edilen verilerin değerlendirilmesi sonucunda, katılımcı öğretmenlerin bilimin doğasının birçok boyutu 
hakkında naif görüşlere sahip oldukları ortaya çıkmıştır. Aynı zamanda öğretmenlerin bu görüşlerinin sınıf uygulamalarına doğrudan etki etmediği görülmüştür. Yanı sıra, katılımc1 fen ve teknoloji öğretmenlerinin sınıf içi uygulamalarını belirleyen en önemli etkenlerin başında algılanan müfredat, okul idarecileri, öğrenci ve velilerin istek ve beklentileri ile sınav sistemi olduğu yönünde bulgulara ulaşılmıştır.

$\mathrm{Bu}$ konudaki araştırmalar hala devam etmekle birlikte ülkemizde bilimin/bilimsel bilginin doğası konusunda yapılan araştırmaların, yurt dışında yapılan araştırmalara kıyasla oldukça az olduğu açıktır. Dolayısıyla, bilimin doğası ve bilim felsefesi öğrenme ve öğretim faaliyetlerinde bu kadar etkiliyken yapılması gereken; öğretmenleri mümkün olduğu kadar erken, örneğin lisans eğitimi dönemlerinde bilim doğası ve bilim felsefesiyle tanıştırmak ve daha sonra da bu konuda çağdaş bir anlayışa sahip olmalarına yardımcı olmaktır (Bilen, 2012). Bu da ancak, geleceğin öğretmenleri olacak her kademedeki öğretmen adaylarının bilimsel bilginin doğası konusundaki bilgi ve anlayışlarının tespit edilerek eksik bilgi ve yanlış anlayışlarının giderilmesi ile mümkün olabilir. Bununla beraber, yapılan çalışmaların çoğunlukla fen ve teknoloji öğretmen/öğretmen adayları ile yürütüldüğü, genel olarak öğretmen adaylarının görüşlerinin düzeyinin genel bir değerlendirmesinin yapıldığı, ayrıca söz konusu görüşlerin tespitinde sınıf seviyesi, cinsiyet vb. değişkenlerin çoğu çalışmada göz ardı edildiği dikkati çekmektedir. Oysaki bu tür değişkenlerin öğrenme sürecinde birçok faktörü etkileyen belirleyici özellikler olduğunu gösteren çalışmalar alan yazında mevcuttur. Örneğin bilimsel bilginin doğası konusu ile ilgili olarak Saraç (2012)'ın çalışmasından elde edilen bulgulara göre, öğretmen adaylarının görüşlerinde bilim insanının karakteristik özelliklerinin cinsiyete göre farklılık gösterdiği düşüncesinin hâkim olduğu görülmüştür. Bununla beraber Güneş (2010) ise çalışmasında cinsiyet değişkeninin, bilimsel düşünce açısından fark yarattığını bulmuştur. $\mathrm{Bu}$ durumun temel nedenlerini, son yıllarda kızların fen bilimlerine daha fazla rağbet göstermesi ve eğitim fakültelerinde fen alanı bölümlerini de yoğun olarak tercih etmelerine bağlamıştır. Ayrıca kızların bilimsel bakış açısına sahip olmaları ve fen okur-yazarlığı konusunda olumlu ilerleme kaydetmelerini de bulgularına neden olarak göstermiştir. Dolayısıyla cinsiyete yönelik birbirinden farklı bu bulgular, öğretmen adaylarının bilimsel bilginin doğasına yönelik görüşlerinin belirlenmesi noktasında cinsiyet vb. diğer değişkenlerin de dikkate alınmasının gerekliliğini ortaya koymaktadır. Bununla beraber yukarıda vurgulanan bulgular 1şığında, öğretmen adaylarının bilimsel bilginin doğası anlayışları tespit edilerek, görülen eksikliklerin giderilmesi büyük önem arz etmektedir. Buradan hareketle çalışmada; fen bilgisi öğretmeni adaylarının bilimin doğası anlayışlarının çeşitli değişkenler açsından incelenerek tespit edilmesi amaçlanmıştır.

\section{Araştırma Soruları}

- Fen bilgisi öğretmeni adaylarının bilimsel bilginin doğası anlayışları genel olarak ne düzeydedir?

- Fen bilgisi öğretmeni adaylarının bilimsel bilginin doğası ölçeğinden elde edilen puanları arasında cinsiyetler açısından anlamlı bir farklılık var mıdır? 
- Fen bilgisi öğretmeni adaylarının bilimsel bilginin doğası ölçeğinden elde edilen puanları arasında sınıf düzeyleri açısından anlamlı bir farklılık var mıdır?

\section{Yöntem}

\section{Araştırma Modeli ve Örneklem}

$\mathrm{Bu}$ araştırma, bir grubun belirli özelliklerini belirlemek için verilerin toplanmasını amaçlayan (Büyüköztürk, Kılıç-Çakmak, Akgün, Karadeniz, \& Demirel, 2011) tarama çalışması olarak desenlenmiştir. Araştırma, 2013-2014 eğitim-öğretim yılı Bahar dönemin sonunda, Atatürk Üniversitesi Kazım Karabekir Eğitim Fakültesi Fen Bilgisi Eğitimi anabilim dalında öğrenimine devam eden öğretmen adayları ile yürütülmüştür. Söz konusu öğretmen adayları olasılık temelli örnekleme yöntemlerinden biri olan basit tesadüfî örnekleme ile belirlenmiş olup; araştırma, veri toplama aracındaki sorulara uygun şekilde yanıtlar veren 196 öğretmen adayından elde edilen veriler ile gerçekleştirilmiştir. Bu örnekleme yönteminde araştırmacı yakın olan ve erişilmesi kolay olan bir durumu seçer. Dolayısıyla bu örnekleme yöntemi araştırmaya hız ve pratiklik kazandırır (Yıldırım \& Şimşek, 2006). Araştırmaya dâhil edilen öğretmen adaylarının demografik özelliklerine ait bilgiler ise Tablo 1'de verilmiştir.

Tablo 1

Öğretmen Adaylarının Cinsiyet ve Sinıf Düzeylerine Göre Dă̆ılımı

\begin{tabular}{cccccc}
\hline Cinsiyet & 1.Sinif & 2.Sinif & 3.Sinif & 4.Sinif & Toplam \\
\hline Bayan & 35 & 43 & 38 & 32 & 148 \\
\hline Bay & 12 & 15 & 8 & 13 & 48 \\
\hline Toplam & 47 & 58 & 47 & 45 & 196 \\
\hline
\end{tabular}

\section{Veri Toplama Araçları ve Analiz Teknikleri}

Araştırmada Atatürk Üniversitesi Kazım Karabekir Eğitim Fakültesinde öğrenim görmekte olan fen bilgisi öğretmen adaylarının bilimin doğasına yönelik anlayışlarını belirlemek amacıyla bir anketten yararlanılmıştır. Veri toplama aracı olarak kullanılan anket formunun ilk kısmında katılımcıların demografik özelliklerine ait bilgileri, ikinci kısmında bilimsel bilginin doğası anlayışlarını belirlemek için 48 maddeden oluşan 5'li Likert tipi bir ölçek yer almaktadır. Söz konusu Likert ölçek, daha önce Rubba ve Andersen (1978) tarafından geliştirilen ve Kılıç, Sungur, Çakıroğlu ve Tekkaya (2005) tarafindan öğretmen adaylarına uygun olarak Türkçe'ye uyarlanan "Bilimsel Bilginin Doğası Ölçeği”dir. Sözkonusu ölçek "ahlâki (amoral)", "yaratıcılık (creative)", "gelişimsellik (developmental)", "sadelik (parsimonious)", "test edilebilirlik (testable)" ile "bütünlük (unified) olmak üzere toplam 6 alt boyuttan oluşmaktadır. Her bir alt boyut dört tanesi pozitif ve dört tanesi de negatif puanlanan 8 maddeden oluşmaktadır (Karaman ve Apaydın, 2014). 
Likert tipi ölçekte yer alan olumlu ifadeler; Kesinlikle Katılmıyorum "1", Katılmıyorum "2", Kısmen Kat1lyorum "3", Kat1liyorum "4", "Kesinlikle Kat1liyorum "5" şeklinde puanlandırılırken, olumsuz anlamlı ifadeler ters şekilde puanlandırılmıştır. Aritmetik ortalamalar yorumlanırken 1.00-1.80 arasındaki değerler "çok düşük", 1.81-2.60 arasındaki değerlerin "düşük", 2.61-3.40 arasındaki değerlerin "orta", 3.41-4.20 arasındaki değerler "yüksek" ve 4.21-5.00 arasındaki değerler "çok yüksek" derecesinde gerçekleştiği kabul edilmiştir (Kutu \& Sözbilir, 2011).

Çalışmada kullanılan örneklem grubunun orijinal ölçekte kullanılan örneklem grubundan farklı olması nedeniyle, ölçekteki ifadelerin anlaşılabilirliği konusunda alan eğitimi uzmanları ile dil bilimcilerin görüş ve önerileri doğrultusunda gerekli incelemeler yapılmış ve sadece demografik özelliklere ait bölümde düzeltmeler yapılmıştır. Yapılan bu kontrollerde ölçek ifadelerinin bilimin doğasına yönelik görüşleri belirleyici nitelikte, kolay anlaşılabilir olduğu, öğretmen adayları üzerinde yapılan ön uygulama sonuçlarından elde edilen bulgularda görülmüştür. Bu çalışma kapsamında ölçeğin Cronbach Alpha 0.81 olarak hesaplanmıştır.

Fen bilgisi öğretmen adayları tarafından cevaplanan ölçekten elde edilen analizinde SPSS paket programı kullanılmıştır. Ahlaki, yaratıcılık, gelişimsellik, sadelik, test edilebilirlik ve bütünlük alt boyutlarını oluşturan bağımlı değişkenlerin cinsiyet ve sınıf düzeyi bağımsız değişkenlerine göre farklılık gösterip göstermediği çok değişkenli varyans analizi (MANOVA) ile test edilmiştir. Analiz öncesinde MANOVA'nın varsayımları test edilmiş ve verilerin MANOVA yapmaya uygun olduğu görülmüştür.

\section{Bulgular}

Çalışmanın bu aşamasında, öğretmen adaylarından toplanan veriler araştırma soruları kapsamında test edilmiş ve elde edilen bulgular tablolar halinde sirasıyla sunulmuştur.

Fen Bilgisi Öğretmeni Adaylarının Bilimsel Bilginin Doğası Anlayışları Genel Olarak Ne Düzeydedir?

Tablo 2'de görüldüğ̈̈ gibi, öğretmen adaylarının tüm boyutlara katılımının orta düzeyde olmakla birlikte ahlaki $(\bar{X}=3.07)$ ve sadelik $(\bar{X}=3.08)$ alt boyutlarına ait puanlarının diğer boyutlara göre oldukça düşük olduğu belirlenmiştir. Ölçeğin genelinden elde edilen puanlara bakıldığında da öğretmen adaylarının ölçekteki ifadelere orta derecede katıldığı görülmektedir. 
Tablo 2

Öğretmen Adaylarının Genel Puanlarına Ait Betimsel Ístatistikler

\begin{tabular}{cccc}
\hline Alt Boyutlar & $n$ & $\bar{X}$ & SS \\
\hline Ahlaki & 196 & 3.07 & 0.380 \\
\hline Yaratıcılık & 196 & 3.20 & 0.536 \\
\hline Gelişimsellik & 196 & 3.27 & 0.784 \\
\hline Sadelik & 196 & 3.08 & 0.475 \\
\hline Test edilebilirlik & 196 & 3.21 & 0.551 \\
\hline Bütünlük & 196 & 3.29 & 0.713 \\
\hline Ölçeğin Geneli & 196 & 3.19 & 0.393
\end{tabular}

Fen Bilgisi Öğretmeni Adaylarının Bilimsel Bilginin Doğası Ölçeğinden Elde Edilen Puanları Arasında Cinsiyetler Açısından Anlamı Bir Farklılık Var Mıdır?

Tablo 3'de görüldüğ ü gibi, erkek öğretmen adaylarının sadece yaratıcılık ( $\bar{X}=3.26$ ) ve sadelik ( $\bar{X}=3.11$ ) alt boyutlarına ait puanlarının kız öğretmen adaylarının puanlarından (sırasıyla $\bar{X}=3.18$ ve $\bar{X}=3.07$ ) daha yüksek olduğu görülmektedir. Ölçeğin genelinden elde edilen puanlara bakıldığında ise her iki grubun da ölçekteki ifadelere orta derecede katıldığ1 görülmektedir.

Tablo 3

Öğretmen Adaylarının Cinsiyete Göre Puanlarına Ait Betimsel İstatistikler

\begin{tabular}{ccccc}
\hline Alt Boyutlar & Cinsiyet & $n$ & $\bar{X}$ & $S S$ \\
\hline \multirow{2}{*}{ Ahlaki } & Kiz & 148 & 3.07 & 0.405 \\
& Erkek & 48 & 3.07 & 0.296 \\
\hline \multirow{2}{*}{ Yaratıcılık } & Kiz & 148 & 3.18 & 0.543 \\
& Erkek & 48 & 3.26 & 0.511 \\
\hline \multirow{2}{*}{ Gelişimsellik } & K1z & 148 & 3.30 & 0.810 \\
& Erkek & 48 & 3.19 & 0.699 \\
\hline \multirow{2}{*}{ Sadelik } & Kiz & 148 & 3.07 & 0.490 \\
& Erkek & 48 & 3.11 & 0.431 \\
\hline \multirow{2}{*}{ Test edilebilirlik } & Kiz & 148 & 3.22 & 0.572 \\
& Erkek & 48 & 3.16 & 0.483 \\
\hline \multirow{2}{*}{ Bütünlük } & Kiz & 148 & 3.31 & 0.708 \\
& Erkek & 48 & 3.23 & 0.730 \\
\hline \multirow{2}{*}{ Ölçeğin Geneli } & Kiz & 148 & 3.19 & 0.395
\end{tabular}

Çalışmada bilimsel bilginin doğası ölçeğinde elde edilen verilerin cinsiyete bağlı olarak yapılan analizleri sonucunda ortalamalar arasında tespit edilen ortalama farklarının 
istatistiksel olarak anlamlı olup olmadığı çok değişkenli varyans analizi (MANOVA) ile test edilmiş ve analiz sonucunda ortalamaların birbirinden anlamlı ölçüde farklılaşmadığ ortaya çıkmıştır [Wilks' Lambda $(\Lambda)=0.980, F=0.652 ; \mathrm{p}>0.05$ ].

Yapılan iki yönlü izleme analizi sonucunda da, tüm alt boyutlara ait ortalamalar arasında cinsiyete bağlı olarak anlamlı bir farklılığın olmadığı tespit edilmiştir (Tablo 4).

Tablo 4

Ölçeğin Alt Boyutlarına Ait Puanların MANOVA sonuçları

\begin{tabular}{cccccc}
\hline Bağımlı Değişken & $K T$ & $S D$ & $K O$ & $F$ & $p$ \\
\hline Ahlaki & 0.001 & 1 & 0.001 & 0.004 & 0.949 \\
Yaratıcılık & 0.235 & 1 & 0.235 & 0.819 & 0.367 \\
Gelişimsellik & 0.443 & 1 & 0.443 & 0.720 & 0.397 \\
Sadelik & 0.064 & 1 & 0.064 & 0.281 & 0.596 \\
Test edilebilirlik & 0.119 & 1 & 0.119 & 0.390 & 0.533 \\
Bütünlük & 0.247 & 1 & 0.247 & 0.484 & 0.487
\end{tabular}

KT: Kareler toplamı, $\quad$ SD: Serbestlik derecesi, $\quad$ KO: Kareler ortalaması

Fen Bilgisi Öğretmeni Adaylarının Bilimsel Bilginin Doğası Ölçeğinden Elde Edilen Puanları Arasında Sınıf Düzeyleri Açısından Anlamı Bir Farklılık Var Mıdır?

Tablo 5'te görüldüğü gibi, sınıf düzeyine göre yapılan analizlerde ahlaki, yaratıcılık test edilebilirlik alt boyutlarında 3. sınıftaki öğretmen adaylarının en yüksek (sırasıyla $\bar{X}$ $=3.18, \bar{X}=3.29$ ve $\bar{X}=3.37$ ) ortalamaya sahip olduğu görülmektedir. Benzer şekilde, gelişimsellik ile bütünlük alt boyutlarında 1. sınıftaki öğretmen adaylarının en yüksek (sırasıyla $\bar{X}=3.41$ ve $\bar{X}=3.47$ ); sadelik alt boyutunda ise 2. sinıftaki öğretmen adaylarının en yüksek ( $\bar{X}=3.19$ ) ortalamaya sahip olduğu belirlenmiştir. Çalışmada ayrıca 4 . sınıftaki öğretmen adaylarının tüm alt boyutlarda en düşük ortalamaya sahip olduğu ortaya çıkmıştır.

Ölçeğin genelinden elde edilen puanlara bakıldığında, tüm sınıfların ölçekteki ifadelere orta derecede katılmakla birlikte 1, 2 ve 3. sinıfların puan ortalamalarının birbirine yakın ve 4. sinıflara göre daha yüksek düzeyde olduğu belirlenmiştir (Tablo 5). 
Tablo 5

Öğretmen Adaylarının Sınıf Düzeylerine Göre Puanlarına Ait Betimsel İstatistikler

\begin{tabular}{|c|c|c|c|c|}
\hline Alt Boyutlar & Siniflar & $n$ & $\bar{X}$ & $S S$ \\
\hline \multirow{4}{*}{ Ahlaki } & 1.Sinıf & 47 & 3.08 & 0.330 \\
\hline & 2. Sinif & 58 & 3.08 & 0.337 \\
\hline & 3. Sinif & 46 & 3.18 & 0.386 \\
\hline & 4. Sinif & 45 & 2.93 & 0.441 \\
\hline \multirow{4}{*}{ Yaratıcılık } & 1.Sinif & 47 & 3.21 & 0.383 \\
\hline & 2. Sinif & 58 & 3.21 & 0.563 \\
\hline & 3. Sinif & 46 & 3.29 & 0.509 \\
\hline & 4. Sinif & 45 & 3.09 & 0.650 \\
\hline \multirow{4}{*}{ Gelişimsellik } & 1.Sinif & 47 & 3.41 & 0.947 \\
\hline & 2. Sinif & 58 & 3.33 & 0.614 \\
\hline & 3. Sinif & 46 & 3.33 & 0.689 \\
\hline & 4. Sinif & 45 & 3.00 & 0.843 \\
\hline \multirow{4}{*}{ Sadelik } & 1.Sinif & 47 & 3.14 & 0.376 \\
\hline & 2. Sinif & 58 & 3.19 & 0.467 \\
\hline & 3. Sinif & 46 & 3.03 & 0.381 \\
\hline & 4. Sinif & 45 & 2.95 & 0.620 \\
\hline \multirow{4}{*}{ Test edilebilirlik } & 1.Sinif & 47 & 3.26 & 0.418 \\
\hline & 2. Sinif & 58 & 3.19 & 0.461 \\
\hline & 3. Sinif & 46 & 3.37 & 0.500 \\
\hline & 4. Sinif & 45 & 3.02 & 0.752 \\
\hline \multirow{4}{*}{ Bütünlük } & 1.Sinif & 47 & 3.47 & 0.670 \\
\hline & 2. Sinif & 58 & 3.34 & 0.542 \\
\hline & 3. Sinif & 46 & 3.28 & 0.539 \\
\hline & 4. Sinif & 45 & 3.05 & 0.985 \\
\hline \multirow{4}{*}{ Ölçeğin Geneli } & 1.Sinif & 47 & 3.26 & 0.289 \\
\hline & 2. Sinif & 58 & 3.22 & 0.312 \\
\hline & 3. Sinif & 46 & 3.25 & 0.334 \\
\hline & 4. Sinif & 45 & 3.19 & 0.558 \\
\hline
\end{tabular}

Tablo 6

Ölçeğin Alt Boyutlarına Ait Puanların MANOVA Sonuçları

\begin{tabular}{cccccc}
\hline Bă̆ımlı Değişken & $K T$ & $S D$ & $K O$ & $F$ & $p$ \\
\hline Ahlaki & 1.432 & 3 & 0.477 & 3.425 & 0.018 \\
Yaratıcılık & 0.862 & 3 & 0.287 & 1.002 & 0.393 \\
Gelişimsellik & 4.514 & 3 & 1.505 & 2.505 & 0.060 \\
Sadelik & 1.672 & 3 & 0.557 & 2.525 & 0.059 \\
Test edilebilirlik & 2.968 & 3 & 0.989 & 3.377 & 0.019 \\
Bütünlük & 4.398 & 3 & 1.466 & 2.974 & 0.033 \\
\hline
\end{tabular}

Çalışmada bilimsel bilginin doğası ölçeğinde elde edilen verilerin sınıf düzeyine bağlı olarak yapılan analizleri sonucunda ortalamalar arasında tespit edilen ortalama farklarının istatistiksel olarak anlamlı olup olmadığı çok değişkenli varyans analizi 
(MANOVA) ile test edilmiş ve analiz sonucunda ortalamaların birbirinden anlamlı ölçüde farklılaştığı ortaya çıkmıştır [Wilks' Lambda $(\Lambda)=0.828, F=2.032 ; \mathrm{p}<0.05$ ].

Yapılan iki yönlü izleme analizi sonucunda da, yaratıcılık, gelişimsellik ve sadelik alt boyutlarına ait ortalamalar arasında sınıf düzeyine bağlı olarak anlamlı bir farklılık olmamasına ( $p>0.05)$ rağmen diğer alt boyutlarda anlamlı farklılığın olduğu $(p<0.05)$ tespit edilmiştir (Tablo 6).

Çalışmada ayrıca farklılığın ortaya çıktığı ahlaki, test edilebilirlik ve bütünlük alt boyutlarına ait ortalamalar arasındaki farklılığın kaynağını bulmak amacıyla Tukey HSD çoklu karşılaştırma testi yapılmıştır. Buna göre ahlaki alt boyutuna yönelik yapılan çoklu karş1laştırma testine göre, öğrencilerin bu boyuta ait ortalama puanları için sadece 3 . ve 4 . sinıflar arasında 3. sınıflar lehine anlamlı farklılık bulunmuştur (Tablo 7).

Tablo 7

Ahlaki Alt Boyutuna İlişkin Tukey HSD Çoklu Karşılaştırma Sonuçları

\begin{tabular}{lccc}
\hline \multirow{2}{*}{ Sinıflar } & $n$ & \multicolumn{2}{c}{ Alt gruplar } \\
\cline { 2 - 4 } & & 1 & 2 \\
\hline 4. Sinıf & 45 & 2.9333 & 3.0771 \\
1. Sinıf & 47 & 3.0771 & 3.0841 \\
2. Sinıf & 58 & 3.0841 & 3.1821 \\
3 Sinıf & 46 & & 0.511 \\
\hline Önem düzeyi & & 0.196 & \\
\hline
\end{tabular}

Çalışmada test edilebilirlik alt boyutuna yönelik yapılan çoklu karşılaştırma testine göre, öğrencilerin bu boyuta ait ortalama puanları için sadece 3. ve 4. sinıflar arasında 3. sınıflar lehine anlamlı farklılık bulunmuştur (Tablo 8).

Tablo 8

Test Edilebilirlik Alt Boyutuna İlişkin Tukey HSD Çoklu Karşılaştırma Sonuçları

\begin{tabular}{lccc}
\hline \multirow{2}{*}{ Sinıflar } & $n$ & \multicolumn{2}{c}{ Alt gruplar } \\
\cline { 2 - 4 } & & 1 & 2 \\
\hline 4. Sinıf & 45 & 3.0167 & 3.1853 \\
2. Sinıf & 58 & 3.1853 & 3.2606 \\
1. Sinıf & 47 & 3.2606 & 3.3668 \\
3 Sinıf & 46 & & 0.353 \\
\hline Önem düzeyi & & 0.122 & \\
\hline
\end{tabular}

Çalışmada son olarak bütünlük alt boyutuna yönelik yapılan çoklu karşılaştırma testine göre, öğrencilerin bu boyuta ait ortalama puanları için sadece 1. ve 4. sinıflar arasında 1. sınıflar lehine anlamlı farklılık bulunmuştur (Tablo 9). 
Tablo 9

Bütünlük Alt Boyutuna İlişkin Tukey HSD Çoklu Karşılaştırma Sonuçları

\begin{tabular}{lccc}
\hline \multirow{2}{*}{ Siniflar } & $n$ & \multicolumn{2}{c}{ Alt gruplar } \\
\cline { 2 - 4 } & & 1 & 2 \\
\hline 4. Sinıf & 45 & 3.0472 & 3.2799 \\
3. Sinıf & 46 & 3.2799 & 3.3427 \\
2. Sinıf & 58 & 3.3427 & 3.4734 \\
1 Sinıf & 47 & & 0.528 \\
\hline Önem düzeyi & & 0.166 & \\
\hline
\end{tabular}

\section{Sonuç ve Tartışma}

Günümüzde yapılan birçok çalışmada gerek öğrencilerin gerekse öğretmen adaylarının bilimin/bilimsel bilginin doğası konusunda yeterli bir anlayışa sahip olmadıkları belirtilmektedir (Abd-El-Khalick ve diğerleri, 1998; Bell \& Lederman, 2003; Karaman \& Apaydın, 2014; Kılıç ve diğerleri, 2005; Özmusul, 2012). Ayrıca, 1999 TIMSS-R raporu ve 2006 PISA gibi uluslararası karşılaştırma ve değerlendirme raporları, bilimin doğası ile ilgili çeşitli alt-ölçekler yönünden Türkiye'nin en alt seviyelerde olduğunu göstermektedir (Köseoğlu ve diğerleri, 2008). Bu durum geleceğimizi yetiştirmekle görevli öğretmenlerin ve dolayısıyla öğretmen adaylarının bilimsel bilginin doğası anlayışlarını incelemeyi ve ortaya çıkarılan eksikliklerin giderilmesini gerekli kılmaktadır. Buradan hareketle bu çalışmanın öğretmen adaylarının bilimsel bilginin doğası anlayışlarının ne düzeyde olduğunu belirlemesi açısından önemli olduğu düşünülmektedir.

Çalışmanın bulguları genel olarak değerlendirildiğinde öğretmen adaylarının ölçekteki ifadelere orta düzeyde katıldıkları görülmektedir. $\mathrm{Bu}$ durum öğretmen adaylarının bilimsel bilginin doğası konusunda az da olsa bir anlayışa sahip olduklarını göstermektedir. Ancak söz konusu öğretmen adaylarının gerek lisans öncesinde gerekse lisans eğitimleri sırasında bilimin doğası konusuna yönelik anlayış kazandırılmasına rağmen çok yüksek puan ortalamasına sahip olmaması bu anlayışlarının daha da geliştirilmesinin gerekliliğini ortaya koymaktadır. Nitekim Parkinson (2004) da, bilimin doğası konusunda öğrencilerini iyi bir donanımla yetiştirmelerini beklenen öğretmenlerin, üniversite eğitimleri boyunca bu alanda yeterince iyi bir eğitim almadıklarını belirterek bu konudaki var olan eksikliğe dikkati çekmiştir. Lucas \& Roth (1996) ile Altun-Yalçın ve diğerleri (2010) da öğretmen adayı olan öğrencilerin bilimin doğası konusundaki görüşlerinin, daha önce aldıkları eğitimden kaynaklandığını ve öğrencilere okullarda verilen bilim eğitiminin bilimsel bilginin doğası hakkındaki fikirlerini etkilediğini ifade ederek benzer görüşlerini ortaya koymuşlardır.

Çalışmada elde edilen bulgular genel olarak alt boyutlar açısından değerlendirildiğinde, öğretmen adaylarının bütün boyutlara orta düzeyde katılmakla birlikte ahlaki ve sadelik alt boyutlarına ait puan ortalamalarının diğer boyutlardan daha düşük olduğu belirlenmiştir. Bu çalışmaya benzer şekilde Kılıç ve diğerleri (2005), Güneş (2010) ile Karaman \& Apaydın (2014) tarafından yapılan çalışmalarda, öğretmen adaylarının sadelik alt boyutunda en düşük ortalamaya sahip olduğu ortaya çıkmıştır. Bu bulgu öğretmen adaylarının bilimsel bilginin daha kompleks ve spesifik olduğuna dair bir 
anlayışa sahip olduklarını göstermektedir. Bunun nedeni öğretmen adaylarının bilimsel konuların daha çok bilim insanlarının çalışma alanı olarak düşünmelerinden kaynaklanabilir. Nitekim Saraç (2012) tarafindan yapılan çalışmanın sonuçları da bu bulguyu destekler niteliktedir. Çalışmada ayrıca öğretmen adaylarının ölçeğin ahlaki alt boyutuna ait diğer boyutlardan daha düşük ortalamaya sahip oldukları belirlenmiştir. Güneş (2010)'un ifade ettiği gibi ahlaki boyut, bilimsel bilginin sonuçlarının tartışılmasından ziyade, süreçte ki katkıları ve bilginin üretimindeki asıl amacın sorgulanmasına dayalı bir yaklaşımdır. Dolayısıyla öğretmen adaylarııın ahlaki boyuta ait puan ortalamalarında alan yazındaki benzer çalışmaların (Güneş, 2010; Karaman \& Apaydın, 2014) aksine diğer boyutlardan daha düşük çıkması bu konudaki yetersizliklerinin olduğunu ortaya düşündürebileceği gibi, örneklem grubunun özellikleri veya aldıkları eğitimin yeterliliği açısından da tartışma konusu sayılabilir. Dolayısıyla bu gibi farklılıklarının nedenlerine yönelik daha detaylı çalışmalara ihtiyaç olduğu söylenebilir.

Çalışmada yaratıcılık alt boyutuna ait genel ortalama puanlara bakıldığında öğretmen adaylarının orta düzeyde bir katılım gösterdikleri anlaşılmaktadır. Bu bulgu öğretmen alan yazındaki bazı çalışmalardan (Akçay, 2011; Demir \& Akarsu, 2013) elde edilen bulguların aksine adaylarının bilimin üretilme aşamasında kısmen de olsa yeterli bilgiye sahip olduklarını göstermekle birlikte bu konudaki anlayışlarının daha da geliştirilmesi gerekli görülmektedir.

Çalş̧̧ada gelişimsellik alt boyutu ile ilgili olarak öğretmen adaylarının genel puan ortalamalarının orta düzeyde olduğu görülmektedir. Bu bulgu çalışma açısından sevindirici olup öğretmen adaylarının bilimsel bilginin değişebilirliğini kabul ettiklerinin bir göstergesi olarak düşünülebilir. Bu bulgular alan yazındaki birçok çalışmayla paralellik göstermektedir (Aslan ve diğerleri, 2009; Doğan-Bora, 2005; Liu \& Lederman, 2002; Yakmaci, 1998). Nitekim Polat (2011) çalışmasında katılımcıların bilimi gelişime ve değişime açık bir etkinlik olarak gördüklerini, bilimsel bilgileri de sorgulanabilir bilgiler olarak kabul ettiklerini ve bilimsel bilgileri bütün hatalardan azade olarak algıladıkları ifade ederek bu çalışmaya benzer bulgularını ortaya koymuştur.

Test edilebilirlik ile ilgili genel ortalama puanlar değerlendirildiğinde, öğretmen adaylarının orta düzeyde bir olumlu anlayışa sahip oldukları belirlenmiştir. Benzer çalışmalarla da (Güneş, 2010; Khisfe \& Lederman, 2006; Kılıç ve diğerleri, 2005) desteklenen bu bulgu öğretmen adaylarının genel olarak bilimin gözlem ve deneylere dayanmasının gerekliliğini, deney sonuçlarının tutarlılığını ve tekrarlanabilirliğini kabul ettiklerini (Polat, 2011) göstermektedir.

Çalışmada bütünlük alt boyutuna ait genel ortalamalara bakıldığında ise öğretmen adaylarının anlayışlarının diğer alt boyutlara benzer şekilde orta düzeyde olduğu ve olumlu görüş belirttikleri görülmektedir. Bu bulgu benzer çalışmalarla da desteklenmektedir (Ayvacı \& Şenel-Çoruhlu, 2012; Güneş, 2010).

Çalışmada elde edilen bulgular cinsiyet değişkenine göre karşılaştırıldığında, gerek ölçeğin geneli gerekse tüm alt boyutları açısından kız ve erkek öğretmen adayları arasında anlamlı bir farklılığın olmamakla beraber, ölçeğin genelinde kız öğrencilerin puan 
ortalamalarının erkeklerden bir miktar fazla olduğu ortaya çıkmıştır. Bu bulgular alan yazındaki bazı çalışmalarla paralellik göstermektedir (Abd-El-Khalick \& Lederman, 2000, Çelikdemir, 2006; Güneş, 2010; Kılıç ve diğerleri, 2005). Bu bulguyu destekler nitelikte Güneş (2010), son y1llarda kız öğrencilerin özellikle eğitim fakültelerinde fen bilimlerini diğer alanlara göre daha fazla tercih etmelerine paralel olarak bilimin doğası ve fen okuryazarlığı konusunda daha olumlu bir bilimsel bakış açısına sahip olmaları şeklinde görüşlerini ifade etmiştir.

Çalışmada elde edilen bulgular sınıf değişkenine göre karşılaştırıldığında ahlaki, test edilebilirlik ve bütünlük boyutlarında sınıflar arasında anlamlı bir farklılığın ortaya çıktığ1 görülmektedir. Söz konusu alt boyutlarda ortaya çıkan bu farklılığın kaynağının belirlenmesi için yapılan çoklu karşılaştırma testlerine ait bulgular incelendiğinde; ahlaki ve test edilebilirlik boyutlarında ortaya çıkan farklılı̆̆ın 3. ve 4. sınıflardan kaynaklandığ 1 anlaşılmaktadır. 3. ve 4. sınıftaki öğretmen adaylarının söz konusu alt boyutlardaki puan ortalamalarına bakıldığında her iki boyutta da 3. sinıfların en yüksek, 4. sinıfların ise en düşük ortalamaya sahip olduğu anlaşılmaktadır. Ayrıca ölçeğin genelinden elde edilen puanlarda da aynı durum söz konusudur. 4. Sınıftaki öğretmen adaylarının puanlarındaki bu düşüşün sebebi olarak öğretmen adaylarının aldıkları derslerin öğretim yöntem ve tekniklerinden, hocaların tutumlarından, KPSS'den kaynaklanan sınav kaygısı vb. nedenler gösterilebilir. Nitekim Saraç (2012) ikinci sınıftaki öğrencilerin beklenenin aksine dördüncü sınıftakilere göre bilimin doğası konusunda daha çok gerçekçi görüşlere sahip olduğunu ortaya koyduğu çalışmasında, bu durumun nedeni olarak sınıf öğretmenliği programında yer alan fen eğitimi derslerinin içerik ve yapısının öğretmen adaylarının bilimin doğası hakkındaki görüşlerini etkilemediği yönünde düşüncelerini ifade etmiştir. Dolayısıyla, öğretmen adaylarının, mezun oldukları öğretmenlik programından bilimin doğası hakkında daha gelişkin bir anlayışla meslek hayatlarına adım atmalarının, bilimsel okuryazar bir nesil yetiştirme amacına hizmet edeceği ortadadır (Karaman \& Apaydın, 2014). Çalışmada farklılığın ortaya çıktığı bütünlük boyutuna ait bulgular incelendiğinde ise ortaya çıkan farklılığın 1. ve 4. sinıflardan kaynaklandığı anlaşılmaktadır. 1. ve 4. sınıftaki öğretmen adaylarının söz konusu alt boyutlardaki puan ortalamalarına bakıldığında 1. sınıfların yüksek, 4. sinıfların ise orta düzeyde katılımının olduğu anlaşılmaktadır. Bu sonuç bizi tekrar fen bilgisi öğretmenliği programında yer alan fen eğitimi derslerinin yeterliliğinin tartışılmasına, ayrıca örneklem grubunun ve dersi veren öğretim elemanın özelliklerine ve dersin veriliş biçimine götürmektedir. Zira yapılan araştırmalar fen programının uygulayıcısı olan öğretmenlerin bilimin doğası hakkında bilgi sahibi olmalarına rağmen derslerine dâhil etmekte ve uygulamakta zorlandıklarını ortaya koymaktadır (Abd-El-Khalick, Bell, \& Lederman, 1998). Bunun yanında öğretmen adaylarının sadece lisans değil, lisans öncesi dönemlerde de bilimin doğası konusuna ne derece yer verildiği ve bu konuda ne düzeyde olumlu bir anlayış geliştirdiklerinin bilinmesinin gerekliliği karşımıza çıkmaktadır. Nitekim bu konuda Şardağ ve diğerleri (2014) tarafından ortaöğretim fen programlarında yer alan kazanımların bilimin doğasını nasıl ve ne oranda yansıttığını ortaya koymak amacıyla yapılan çalışmada, bilimin doğasına vurgu yapan kazanım sayısının tüm programlarda yetersiz olduğu sonucuna ulaşılmıştır. Dolayısıyla bu bulgu, öğretmen adaylarının bilimin doğası anlayışlarının ilgili 
fen programının kazanımlarıyla da ilişkisini gösterebilir. Yanı sıra, şu anda yapılmış olan bu nicel çalışma ile bir nevi durum tespiti yapılmış olup, yapılacak olan ileriki çalışmalarda nitel çalışma yapılıp, bu düşüsün nedeni daha derinlemesine ayrıntılı olarak incelenebilir. 


\section{Kaynakça}

Abd-El-Khalick, F., Bell, R. L., \& Lederman, N. G. (1998). The nature of science and instructional practice: Making the unnatural natural. Science Education, 82, 417-436.

Abd-El-Khalick, F. \& Lederman, N.G. (2000). Improving science teachers' conceptions of the nature of science: A critical review of the literature. International Journal of Science Education, 22, 665-701.

Abd-El-Khalick, F. (2001). Embedding nature of science instruction in preservice elementary science courses: Abandoning scientism, but... Journal of Science Teacher Education, 12(3), 215-233.

Akçay, B. (2011). Fen ve teknoloji öğretmenlerinin bilimin doğasına yönelik inanışları. Trakya Üniversitesi Eğitim Fakültesi Dergisi, 1(1), 145-164.

Akerson, V.L. \& Abd-El-Khalick, F. (2005). How should I know what scientists do?- I am just a kid: Fourth-grade students' conceptions of nature of science. Journal of Elementary Science Education, 17(1), 1-11.

Altun-Yalçın, S., Kahraman, S., Açış1, S., \& Yılmaz, Z.A. (2010). Fen bilgisi öğretmen adaylarının bilimin doğası konusundaki görüşlerinin tespit edilmesi. EÜFBED-Fen Bilimleri Enstitüsü Dergisi, 3(2), 181-197.

American Association For The Advancement of Science [AAAS] (1990). Science for All Americans. Benchmarks for Scientific Literacy. Newyork: Oxford University Press.

American Association for the Advancement of Science [AAAS] (1993). Benchmarks for Science Literacy: A Project 2061 Report. New York: Oxford University Press.

Aslan, O., Yalçın, N., \& Taşar, M. F. (2009). Fen ve teknoloji öğretmenlerinin bilimin doğası hakkındaki görüşleri. Ahi Evran Üniversitesi Eğitim Fakültesi Dergisi, 10(3), $1-8$.

Aslan, O. \& Taşar, M. F. (2013). Fen öğretmenlerinin bilimin doğası görüşleri ve öğretimleri nasıldır? Bir sınıf içi araştırması. Eğitim ve Bilim, 38(167), 65-80.

Ayvacı, H. Ş. \& Şenel-Çoruhlu, T. (2012). Fen ve teknoloji öğretmen adaylarının bilim ve fen kavramları ile ilgili sahip oldukları görüşlerin araştırılması. Dicle Üniversitesi Ziya Gökalp Ĕ̈itim Fakültesi Dergisi, 19, 29-37.

Bell, R.L. \& Lederman, N.G. (2003). Understandings of the nature of science and decision making on science and technology based issues. Science Education, 87, 352-377.

Bilen, K. (2012). Bilimin doğası dersinde örnek bir uygulama: Kart değişim oyunu. Mustafa Kemal Üniversitesi Sosyal Bilimler Enstitüsü Dergisi, 9(18), 173-185.

Büyüköztürk, Ş., Kılıç-Çakmak, E., Akgün, Ö. E., Karadeniz, Ş., \& Demirel, F. (2011). Bilimsel araştırma yöntemleri. Ankara: Pegem Yayıncılık.

Çelikdemir, M. (2006). Examining middle school students' understanding of the nature of science (Yayınlanmamış Y. Lisans Tezi). Orta Doğu Teknik Üniversitesi Sosyal Bilimler Enstitüsü, Ankara.

Çil, E. \& Çepni, S. (2012). Kavramsal değişim yaklaşımı, doğrudan yansıtıcı yaklaşım ve milli eğitim bakanlığı ders kitabının bilimin doğası üzerine görüşler ve Işık 
üniversitesindeki kavramsal değişim üzerine etkileri. Kuram ve Uygulamada Eğitim Bilimleri, 12(2), 1089-1116.

Demir, N. \& Akarsu, B. (2013). Ortaokul öğrencilerinin bilimin doğası hakkında algıları. Journal of European Education, 3(1), 1-9.

Doğan-Bora, N. (2005). Türkiye genelinde ortaöğretim fen branşı ögrretmen ve ögrencilerinin bilimin doğası üzerine görüşlerinin araştırılması (Yayınlanmamış Doktora Tezi). Gazi Üniversitesi Eğitim Bilimleri Enstitüsü, Ankara.

Driver, R., Leach, J., Millar, R., \& Scott, P. (1996). Young peoples' images of science. Buckingham, UK: Open University Press.

Güneş, G. (2010). Öğretmen adaylarının temel astronomi konularında bilgi seviyeleri ile bilimin doğasi ve astronomi özyeterlilikleri arasındaki ilişkinin incelenmesi (Yayınlanmamış Y. Lisans Tezi). Çukurova Üniversitesi Sosyal Bilimler Enstitüsü, Adana.

Gürses, A., Doğar, Ç., \& Yalçın, M. (2005). Bilimin doğası ve yükseköğrenim öğrencilerinin bilimin doğasına dair düşünceleri. Milli Ĕ̆itim Dergisi, 166, http://yayim.meb.gov.tr/dergiler/166/index3-icindekiler.htm

Hogan, K. (2000). Exploring a process view of students' knowledge about the nature of science. Science and Education, 84(1), 51-70.

Karaman, A. \& Apaydın, S. (2014). Fizik, fen bilgisi ve sınıf öğretmenlerinin bilimin doğası konusundaki gelişimleri: Yaz bilim kamp1 örneği. Illköğretim Online, 13(2), 377-393.

Kaya, G. \& Çakmakçı, G. (2012). Fen kavramlarıyla ilişkilendirilmiş doğrudan yansitıcı yaklaşımın ilköğretim ögrrencilerinin bilimin doğası hakkındaki görüşlerine ve akademik başarılarına etkisi. X. Ulusal Fen Bilimleri ve Matematik Eğitimi Kongresi, s:108, Ankara, ODTÜ Kültür ve Kongre Merkezi.

Khisfe, R. \& Lederman, N. (2006). Teaching nature of science within a controversial topic: Integrated versus nonintegrated. Journal of Research in Science Teaching, 43(4), 395418 .

Kılıç, K., Sungur, S., Çakıroğlu, J., \& Tekkaya, C. (2005). Ninth grade students' understanding of the nature of scientific knowledge. Hacettepe Üniversitesi Ë̆itim Fakültesi Dergisi, 28, 127-133.

Köseoğlu, F., Tümay, H., \& Budak, E. (2008). Bilimin doğası hakkında paradigma değişimleri ve öğretimi ile ilgili yeni anlayışlar. Gazi Eğitim Fakültesi Dergisi, 28(2), 221-237.

Kutu, H. \& Sözbilir, M. (2011). Yaşam temelli ARCS öğretim modeliyle 9. sınıf kimya dersi "Hayatımızda Kimya" ünitesinin öğretimi. Ondokuz Mayıs Üniversitesi Ĕgitim Fakültesi Dergisi, 30(1), 29-62.

Lederman, NG. (1992). Students' and teachers' conceptions of the nature science. A review of the research. Journal of Research in Science Teaching, 29(4), 331-359. 
Liu, S. Y. \& Lederman, N. G. (2002). Taiwanese students' views of nature of science. School Science and Mathematics, 102(3), 114-122.

Lucas, K. B. \& Roth, W. M. (1996). The nature of scientific knowledge and student learning: two longitudinal case studies. Research in Science Education, 74, 225-239.

Milli Eğitim Bakanlığ1 [MEB]. (2013). Ortaöğretim biyoloji dersi (9, 10, 11 ve 12. Sinıflar) ögretim programı. Ankara: MEB.

National Research Council. [NRC] (1996). National science education standards, Washington, DC: National Academic Press.

Parkinson, J. (2004). Improving Secondary Science Teaching. New York, NY: RoutledgeFalmer.

Polat, M. (2011). Bilimin doğası hakkındaki görüşlerin kısa hikâyeler yöntemiyle değerlendirilmesi: Fen bilgisi ögretmen adayları örneği (Yayınlanmış Doktora Tezi). Gazi Üniversitesi Eğitim Bilimleri Enstitüsü, Ankara.

Saraç, E. (2012). Sinıf öğretmenleri ve sınıf öğretmeni adaylarının bilimin doğasına ilişkin görüşleri (Yayınlanmamış Y. Lisans Tezi). Akdeniz Üniversitesi Eğitim Bilimleri Enstitüsü, Antalya.

Seçkin, M. (2013). Sekizinci sınıf öğrencilerinin bilimin doğası hakkındaki görüşlerinin belirlenmesi. Eğitim ve İnsani Bilimler Dergisi: Teori ve Uygulama, 4(7), 27-52.

Şardağ, M., Aydın, S., Kalender, N., Tortumlu, S., Çiftçi, M., \& Perihanoğlu, Ş. (2014). Bilimin doğası'nın ortaöğretim fizik, kimya ve biyoloji yeni öğretim programlarında yansitılması. Eğitim ve Bilim, 39(174), 233-248.

Tan, M. \& Temiz, B.K. (2003). Fen öğretiminde bilimsel süreç becerilerinin yeri ve önemi. Pamukkale Üniversitesi Ĕ̈itim Fakültesi Dergisi, 1(13), 89-101.

Taşar, M. F. (2003). Teaching history and the nature of science in science teacher education programs. Pamukkale Üniversitesi Ĕgitim Fakültesi Dergisi, 7(1), 30-42.

Türkmen, L. \& Yalçın, M. (2001). Bilimin doğası ve eğitimdeki önemi. Afyon Kocatepe Üniversitesi Sosyal Bilimler Dergisi, 3(1), 189-195.

Yakmaci, B. (1998). Science (biology, chemistry and physics) teachers'views on the nature of science as a dimension of scientific literacy (Unpublished Master's Thesis). Bogazici University Institute for Graduate Studies in Social Sciences, İstanbul.

Yalçın S A. \& Yalçın S. (2011). Analyzing elementary teachers' views on the nature of science according to their academic levels. Procedia Social and Behavioral Sciences, $15,942-946$.

Yıldırım, A. \& Şimşek, H. (2006). Sosyal bilimlerde nitel araştırma yöntemleri. Ankara: Seçkin Yayıncılık. 